\title{
Climate Change Awareness and Attitudes Among Adolescents in the Czech Republic
}

\author{
Jan Skalík \\ Envigogika 10 (4) - Reviewed Papers/Recenzované články \\ Publikováno/Published dne 5. 12. 2015
}

DOI: $\underline{10.14712 / 18023061.472}$

\begin{abstract}
The distribution of climate change awareness of Czech adolescent students and their climate change related attitudes are analysed in this study. Even though the influence of accessed information on actual behaviour is usually described as rather small by most experimental studies, we argue that the effect of knowledge on specific behaviour becomes significant in a long time perspective. The main focus of the study is thus to offer a segmentation of youth in the issue of climate change related to information sources they trust and also related to the type of information on climate change - such as documents, processes, terms or numeral data.
\end{abstract}

A sample of students from Masaryk University and several grammar schools from Czech Republic participated in the quantitative study focusing on their knowledge of climate change, information sources they use and proenvironmental attitudes.

The survey highlighted the extremely low level of students' knowledge. A strong tie between the amount of accessed information and evaluation of the seriousness of climate change was found. Trust in scientific evidence and effort not to rely only on one source of information does correlate with respondent awareness. Students, who understand climate change well, are often post-materialists. On the other hand, informed students do not feel greater concern and are not more globally focused than others. Although there is no clear relation between awareness and levels of consumerism, the more were the students informed, the more they feel their personal responsibility for climate change. Females are not on average better informed then males, but their feeling of personal responsibility is much higher. The study thus confirmed general expectations about unspecific awareness of climate change in the specific context and presented segmentations of the public for further social-marketing purposes

\section{Key words:}

adolescence, pro-environmental attitudes, awareness, climate change, Czech Republic, environmental behaviour, knowledge

\section{Abstrakt}

Tato studie analyzuje povědomí o změně klimatu u českých dospívajících studentů a zabývá se jejich souvisejícími postoji. I když většina studií popisuje vliv dostupných informací 
na skutečné chování jako poměrně malý, autor chce upozornit na to, že vliv znalostí na určité chování může být významný z dlouhodobého hlediska, přičemž pro tento závěr dosud chyběly akademicky podložené argumenty, a to z metodologických důvodů (Bas, 2010). Hlavním cílem této explorativní studie je tak ukázat názory českých adolescentů na problematiku klimatických změn, a to ve vztahu $\mathrm{k}$ informačním zdrojům, jimž důvěřují, a také ve vztahu $\mathrm{k}$ určitým druhům informací v oblasti změny klimatu - jež jsou součástí dokumentů, procesů, podmínek nebo číselných údajů.

Vzorek studentů z Masarykovy univerzity a z několika středních škol v České republice se (dle vlastního výběru) zúčastnil kvantitativní studie zaměřené na jejich znalosti změny klimatu, na informační zdroje, které používají, a na pro-environmentální postoje.

Šetření odhalilo extrémně nízkou úroveň znalostí studentů. Byla nalezena úzká spojitost mezi množstvím studentům dostupných informací a jejich hodnocením závažnosti klimatických změn. Důvěra studentů ve vědecké poznatky a jejich snaha se neopírat pouze o jediný zdroj informací korelují s jejich povědomím. Studenti, kteří velmi dobře rozumí změnám klimatu, jsou většinou post-materialisté. Na druhé straně, dobře informovaní studenti necítí větší obavy a nejsou více globálně orientovaní než ostatní. I když jasná korelace mezi vědomím a úrovni spotřeby nebyla nalezena, platilo, že čím lépe jsou studenti informováni, tím více se cítí osobně zodpovědni za změnu klimatu. Ženy nemají v průměru lepší informace než muži, ale pocit osobní odpovědnosti je mnohem silnější u žen. Studie tedy potvrdila obecné předpoklady o vágním povědomí o změně klimatu ve specifickém kontextu, jímž se zabývala, a představila rozdělení české studentské populace, což lze dále využít např́ílad v sociálním marketingu.

\section{Klíčová slova}

adolescenti, pro-environmentální postoje, environmentální povědomí, změna klimatu, Česká republika, chování, znalosti 


\section{Introduction}

Climate change has been a major topic of European debates for most of the last decade. This period has witnessed a significant collapse in public and political concern resulting from the failure of the UN Climate Change Conference in Copenhagen and the economic crisis that began in 2009 (Scruggs, 2012). In 2004, $45 \%$ of Europeans and $43 \%$ of Czechs saw climate change as one of five major environmental problems. As the following surveys show, in the last ten years the difference between attitudes in the Czech Republic and in Western European countries has grown dramatically. The goal of this review of related surveys is thus to provide documentation of the differences and similarities between other countries in the EU and the Czech Republic as regards the climate change issue. Until 2007, the number of people in Europe who considered climate change to be one of five major issues rose to $57 \%$ of Europeans and $50 \%$ of Czechs (EC 2004; 2008a). In 2008, climate change (further referred to as CC) was considered as the most threatening issue out of all of global problems by $30 \%$ of Europeans and $23 \%$ of Czechs. Only $45 \%$ of Czechs mentioned it as being among the four most threatening issues, a much smaller percentage than among other European countries, with a country average of $62 \%$ (EC, 2008b). As a consequence of the economic downturn in February 2009, it decreased to $51 \%$ in Europe and $33 \%$ in the Czech Republic (EC, 2009a; Schor, 2014). In November 2013, CC was the most serious global problem only for $16 \%$ of Europeans and $11 \%$ of Czechs, a lot fewer people than in 2009 (EC, 2009b; 2013).

Generalizing these data and a related theoretical meta-analysis (Bamberg, 2007; Zelezny 1999), we may say that the number of Czechs who view CC as a priority is smaller than the European average by one quarter. In the long-term, this disproportion may increase even further, as the average Western European population is better able to react to the increasing scientific warning regarding the urgency of the problem (IPCC, 2014): general awareness in Europe is increasing and, compared to problems relating to adequate concern, there is not such a lack of information (Flavin, 2008). Continual and detailed descriptive data are available thanks to the Iongitudinal Eurobarometer surveys provided by the European Commission. Based on most topic-relevant comparative quantitative surveys, it can be surmised that the Czech public sees itself as the least informed on CC in all of Europe (EC, 2004; 2008a; 2008b; 2009a; 2009b; 2014). In 2014, Czechs were even specifically mentioned as the population in the EU that was feeling least informed on environmental issues (EC, 2014). Another, less frequent, sociological longitudinal survey, the ISSP (Krejčí, 2012) and the national longitudinal survey CVVM (Ďurd'ovič, 2013) also report a low level of knowledge regarding environmental problems.

Why is there such a big difference? When comparing the situation in the Czech Republic with that in Great Britain where CC awareness programmes are seen as a priority (Lorenzoni, 2007), we may identify one reason as the relatively lower effort of Czech experts to cultivate domestic public debate, the relative lack of CC in the school curriculum, and the indifference of the political elites when it comes to dealing with the problem (Wray-Lake 2010; Šaradin 2007). Another important reason for the significantly different position of the public may be Czech pessimism in general (Dosedlová, 2015). As British surveys show youth to be a progressive social group on this issue in respect to improving attitudes towards CC (COI, 2006), high school and university education seems to be a very effective, but underestimated, measure to combat climate change (McKenzie-Mohr, 2013; Inglehart, 1995; Watson, 2012). Bearing this in mind, this paper describes the CC-relevant characteristics of Czech adolescents and proposes a segmentation in order to provide more specific insights and targets for intervention. 
In the following sections, we discuss the design of the survey, the research problem and questions. In the results section, factor analysis is used to indicate the segments of the respondents, and regression statistical methods are applied to find the most important drivers of potential behavioural change. The reliability of different information sources for the survey's respondents is further assessed. Finally, the answers to the main hypothesis and the subsequent findings are discussed.

\section{Theory and hypotheses}

From the wide variety of possible perspectives, we have chosen only a partial one. As our research is framed by explorative goals, we have narrowed our perspective to a particular social subgroup, covering the CC attitudes of Czech adolescents and the educational influences on these attitudes. We have chosen a sample of university and high school students as they represent, socio-demographically, a relatively homogeneous social group, but their CC awareness varies to a large extent. There is also a significant social benefit related to influencing this particular social subgroup (Lorenzoni, 2007).

Our analysis of students' knowledge of $\mathrm{CC}$ and its correlates has been inspired primarily by Ajzen's (1991) theory of attitudes and willingness to act in the environmental context. This theory is widely used to interpret the influence of information dissemination on the development of personal attitudes. Human behaviour is determined mainly by the intention to act, the social norm and the locus of control. Specific knowledge is part of all of these three main determinants. In our research, we draw on Van Meergeren (1995), Lee (2011), Warnars (2008) and Wray-Lake (2010), who focused on the specific influences of knowledge production and the sharing on attitudes. According to numerous applications of Ajzen's Theory of Planned Behaviour, the effect of environmental awareness on a specific behaviour is likely to be very low (Bamberg, 2007). They conclude that problem awareness is probably mediated by moral and social norms, feelings of guilt, and attribution processes. The influence of problem awareness is significantly lower than the attitude towards the behaviour or the behavioural control of the personal moral norm. Nevertheless, according to a survey conducted by the European Commission (2008b), when the respondents were well informed about CC, there was about a one-third increase in their concern about its impacts and about a two-thirds increase in their activity to mitigate CC. In addition, the more people consider any environmental problem to be serious, the greater the lack of information connected to it that they experience (Case, 2012; EC, 2008a; McKenzie-Mohr, 2013). This leads us to the assumption that large scale strategies with the goal of influencing the entire adolescent population may turn out to be ineffective, as the group varies internally. Any of the proposed theories and hypotheses may be significantly influenced by the variety of personal attitudes and preferences in the heterogenic population (McKenzie-Mohr, 2013). Thus it is reasonable not only to test the selected hypothesis, but also to offer a possible segmentation of the sample on the basis of the responses.

Therefore, we may expect that one's awareness and behaviour are mutually dependent and that the understanding of $\mathrm{CC}$ behaviour could be based on general tendencies and a wider time scale (Kaiser, 2006). Habits and social norms are key drivers for actual individual behaviour (Ajzen, 2008; Stevenson, 2014). On the other hand, awareness and theoretical knowledge may be seen as very important for changing one's personal mind-set, worldview (Cordano, Frieze, Ellis, 2004), and long-term personal intellectual development (Watson, 2012).

This led us to concentrate on more detailed research questions. Two main hypotheses for the survey were suggested, both of them consisting of several sub-hypotheses. First, the 
link between the respondents' trust in science, their personal effort to create an opinion about CC, and their awareness of CC was examined to provide a basic insight for the differentiation that followed. Next, the influence of post-materialism - people prioritizing non-material goods in their lives, particularly individual values such as autonomy and selfexpression, as defined by Inglehart (1995) - was discussed, employing the arguments of Řeháková (2004) and Mead (2012), and the awareness of CC concerns was tested. As our first hypothesis, we assumed that trust in academic sources and the effort to create one's own opinion correlate positively with awareness. This hypothesis was supplemented by three sub-hypotheses: (A.1) Respondents with extensive knowledge of CC search for information more often than other respondents. (A.2) Respondents with extensive knowledge of CC trust scientific books and papers more often. (A.3) Respondents with extensive knowledge of CC trust science more and they do not trust politicians with sceptical attitudes towards CC more often (in our case, as an example of such a politician, the former Czech president Václav Klaus, was selected).

The second hypothesis was that post-materialistic values and a cosmopolitan orientation correlate positively with CC awareness and with fear of the impacts of CC. We divided it into: (B.1) Respondents with extensive knowledge of CC feel more cosmopolitan. (B.2) Respondents with extensive knowledge of CC demonstrate post-materialistic values more often. (B.3) Respondents with extensive knowledge of CC express fear of CC more often, and they consider it to be more negative.

\section{Methods and data collection}

In order to answer these 6 sub-hypotheses, the questionnaire consisted of a range of 12 factual questions which were divided into sections on the respondents' familiarity with and understanding of the terms and processes of CC and on their familiarity with and understanding of contemporary societal reaction to CC. Furthermore, the respondents answered 5 questions about their information sources (the frequency of their information inquiry and their trust in the information sources related to CC), a range of 7 questions about their attitudes towards CC (evaluation of the level of the problem's gravity, of their personal influence on CC drivers, and of the impact of CC on their personal life), and 12 sociodemographic questions (including anomy rate scale, subjective class, and post-materialism scale).

As stated above, the study does not depend on self-reference in regards to the respondents' awareness of CC, but we checked it directly with a 12-question test focusing on the concepts which are presented during grammar school lessons or in the media. For example, we asked the respondents to select the right definition of climate from several suggested possibilities, to estimate the correct speed of global warming, or to identify the mission of the Intergovernmental Panel on Climate Change. These questions were selected to cover four topic areas: climate facts, climate processes, facts about the societal response to climate change, and the processes of the societal response to climate change.

We designed the questionnaire according to our assumption of the probable typology of the student population in relation to the types of CC information and sources of information available.

Our research does not attempt to describe the attitudes of the whole of the Czech adolescent or student population, but we have collected our sample of respondents in such a way that it would include a broad variety of significantly different kinds of knowledge, beliefs, motives and attitudes: we included high school students from schools interested in 
CC-focused education and students of the social sciences, varying in their field of study from Energy and Security Studies to Environmental Studies. An internet-administered quantitative survey was provided in a computer-assisted self-interview (CASI) design to the overall population of 1628 undergraduate students with repeated email invitations. In sum, 510 responses were recorded, which equates to a $31.3 \%$ response rate. Seven grammar schools located in Brno with a specific interest in CC education (predominantly in their classes of geography or biology) were also approached. These students answered printed questionnaires (PAPI) during classes and the response rate was above $85 \%$, with 283 comparable responses. As we are presenting the results of a pilot study, we may expect the surveyed sample to have specific features, and the respondents were not chosen by any specific structure, the results may not be representative and therefore it is not possible to extend them to the whole of the Czech student population. These data were then recoded and statistically analysed in SPSS software. Since the structure of the respondents in the sample had similar socio-demographic characteristics (54\% of females; median age 19.2 years; mainly residents of Southern Moravia) to the whole student population at these institutions, weightings were not applied to the data.

\section{Results}

In the following section, we at first describe the responses, with an overview of the typology of the respondents. Secondly, we focus on how the responses reflect upon our hypothesis with respect to the proposed typology of the respondents. Finally, we emphasize that we have to bear in mind the methodological limitations of our exploratory pilot study which can offer only preliminary results.

\subsection{Description of the results and the segmentation}

The respondents' awareness of climate change varied significantly: $81 \%$ of the respondents knew the correct definition of climate, but the difference between climate change and global warming was clear to only $32 \%$ of the respondents. In order to present other descriptive results, we should add that more than 4 out of every 10 respondents thought that global warming is caused by the interception of solar rays, even though the true cause is the interception of heat rays. The respondents did not know about the effect of clouds on warming.

The respondents exaggerated the speed of warming, but on the other hand, half of them underestimated the scientific certainty that $\mathrm{CC}$ is caused by humans. The basics of the ecological footprint, environmental taxation, the objectives of the Intergovernmental Panel on Climate Change or the Stern Review were known to only about a third of the respondents.

Using the Principal Component Analysis (PCA) to describe the types of respondent knowledge, we can confirm that the originally presented division of the topics according to content is not the only one possible (Table 1). After five iterations, we rotated the component matrix by applying the Varimax method with Kaiser Normalization. The data seem to best fit into the following categories as related to type of information: understanding of documents (q07, q08, q10, q11), understanding of processes (q02, q03), knowledge of terms (q01, q04), and numerical knowledge (q05, q06). It was not possible to assign questions "q09" and " $q 12$ " to any of the selected components. These components may also suggest the types of adolescents according to the information type that they most significantly react to. In consideration of this argument, particular strategies of how to approach various students-those with the best orientation in international reports and 
policies, the physical basis of $\mathrm{CC}$, formal definitions and terms or numerical knowledgecould be developed and applied to support the effectiveness of environmental education.

\begin{tabular}{|c|c|c|c|c|}
\hline \multirow{2}{*}{$\begin{array}{l}\text { Rotated Component } \\
\text { Matrix }\end{array}$} & \multicolumn{4}{|c|}{ Component: Knowledge of... } \\
\hline & $\begin{array}{c}(1) \\
\text {...documents }\end{array}$ & $\begin{array}{c}(2) \\
\text {...processes }\end{array}$ & $\begin{array}{l}\text { (3) } \\
\text {...terms }\end{array}$ & $\begin{array}{c}\text { (4) } \\
\text {...numbers }\end{array}$ \\
\hline (q10) Stern Review & 0,65 & & & \\
\hline (q07) Carbon Footprint & 0,61 & & & \\
\hline (q08) Environmental Taxes & 0,56 & & & \\
\hline (q11) Climate Scenarios & 0,56 & & & \\
\hline (q03) Greenhouse Effect & & 0,83 & & \\
\hline (q02) Clim. Change/Global Warm. & & $-0,81$ & & \\
\hline (q04) Not in Greenhouse Gases & & & 0,65 & \\
\hline (q01) Definition of Climate & & & 0,62 & \\
\hline (q09) Role of IPCC & 0,31 & 0,20 & 0,39 & $-0,10$ \\
\hline (q05) Average Temperature & & & & 0,65 \\
\hline (q06) Science Certainty & & & & $-0,63$ \\
\hline (q12) Climate Policies & 0,21 & 0,06 & $-0,33$ & 0,38 \\
\hline
\end{tabular}

Extraction Method: PCA

Rotation Method: Varimax with Caiser Normalization; rotation converged in 5 iterations

Tab. 1 The Components of climate change-related knowledge

Considering that there were four options only for each test question and one of them was always right, if all the respondents were only guessing, they would have scored three out of twelve answers correctly on average. The recorded average of the correct answers in the sample was 5.02 (St. Dev. 2.06).

Based on this data, we can assume that Czech students' awareness regarding the topic of CC is extremely low: the amount of correct responses is only slightly higher than the amount that would have been achieved randomly by guessing. Knowledge of climate science terminology (dark blue in Table 2) is evidenced by even the least-informed respondents; the average respondent was also relatively well informed about terms related to the societal response. Climate and climate policy issues were nevertheless not very well known at all. 


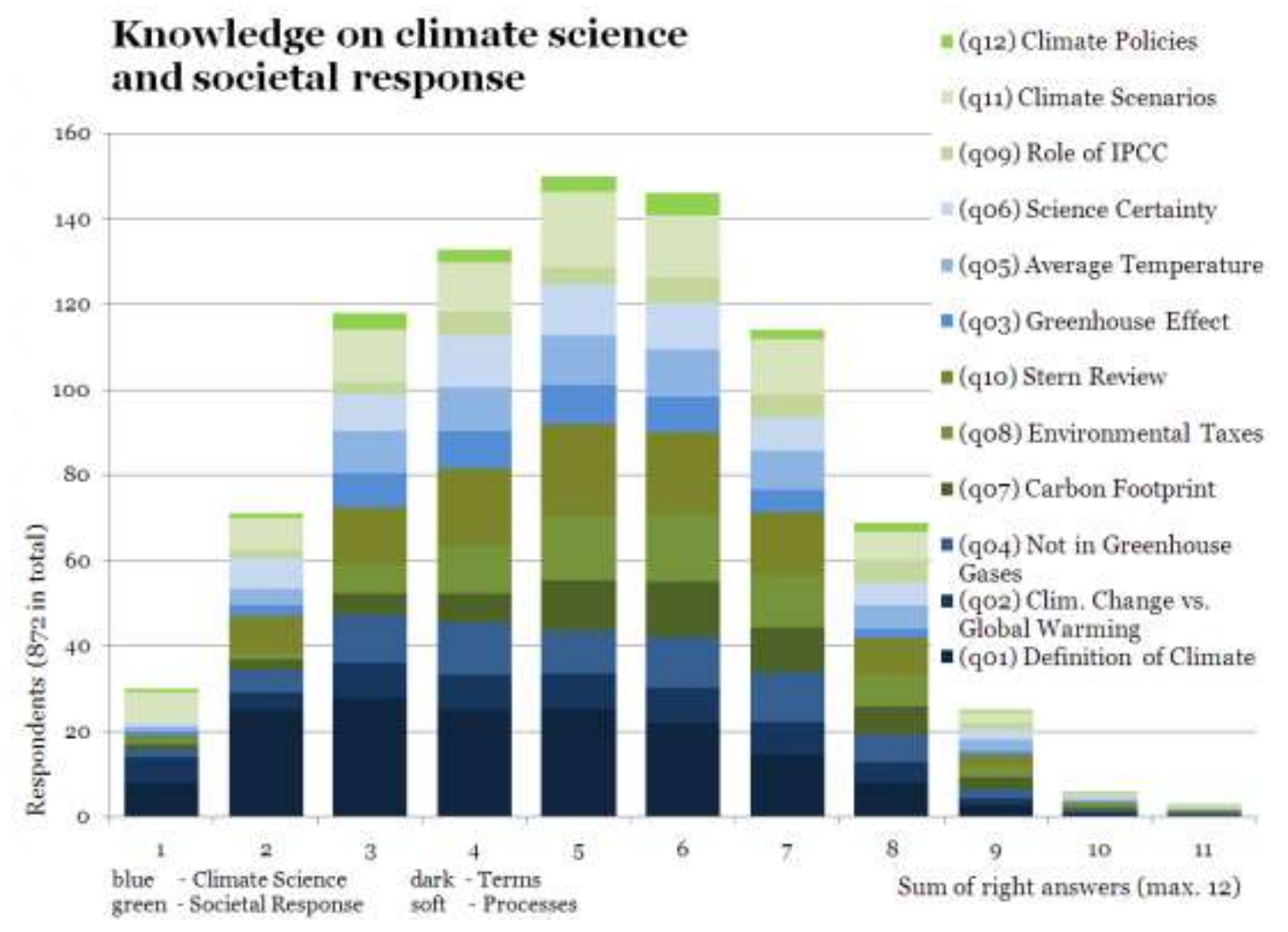

Tab. 2 Distribution of climate change related knowledge

It is quite clear that the more respondents know about climate, the stronger their concern related to $\mathrm{CC}$. The respondents who viewed $\mathrm{CC}$ as definitely a positive phenomenon scored on average 4.1 questions out of a possible 12, while respondents with a perceptibly negative perception of CC recorded a correct answer on average to 5.7 questions.

Furthermore, logistic regression modelling was used to describe the main influences on the level of the respondents' knowledge (Table 3). Among the positive determinants of $\mathrm{CC}$ awareness presented by the regression analysis, age was found to be the biggest positive determinant, followed by grammar school attendance ("gymnázium" in the Czech education system) rather than university attendance, male gender, negative perception of CC impacts, higher frequency of obtaining information about CC, higher feelings of responsibility, and low level of anomy measured by the standard anomy scale (Robinson, 2013). Regression analysis may explain $32 \%$ of data variability ( $R$ Square $=0,326$ ). 


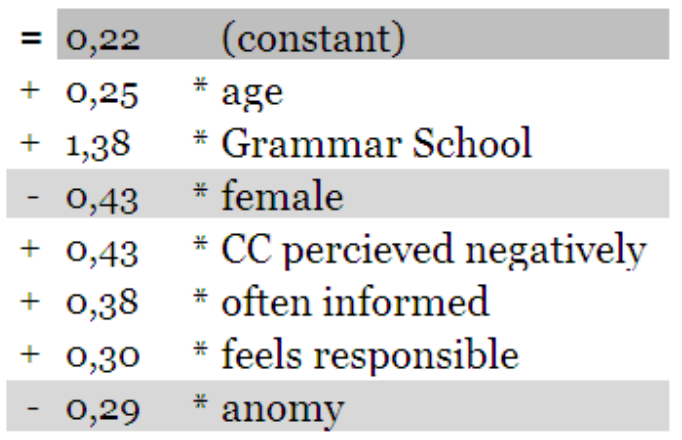

Tab. 3 Logistic regression model : Knowledge of the scientific and societal contexts of climate change

\section{Description of factor:}

grammar school: the subject was from the subgroup of grammar school students CC perceived negatively: rather negative or negative reported perception of CC (q22) often informed: often or very often searches for information on CC (q13) feels responsible: feels definitely or quite responsible for CC (q20) anomy: confirmation of majority of six items of anomy scale

The questionnaire included a section where we asked the respondents about their information sources and the sources' subjective relevance to them. Further segmentation of the surveyed adolescents was thus proposed according to the amount of trust they put in the information obtained and according to the number of times they accessed this type of information. Using the PCA method, after 19 iterations with Kaiser Normalization, five main components were found (Table 4). These may be labelled "trust in scientific sources", "informed by mediators", "trust in the media", "trust in and informed by relatives and friends" and finally as a segment of "informed by direct actors or participants". 
Rotated

\section{Component Matrix}

\begin{tabular}{|c|c|c|c|c|c|}
\hline & $\begin{array}{l}\text { (1) } \\
\text { trustfull } \\
\text { in } \\
\text { scientific } \\
\text { sources }\end{array}$ & $\begin{array}{l}(2) \\
\text { informed } \\
\text { by } \\
\text { mediator } \\
\text { s }\end{array}$ & $\begin{array}{l}\text { (3) } \\
\text { trustfull } \\
\text { in media }\end{array}$ & $\begin{array}{l}\text { trustfull } \\
\text { in and } \\
\text { informed } \\
\text { by } \\
\text { relatives }\end{array}$ & $\begin{array}{c}\text { (5) } \\
\text { informed } \\
\text { by actors }\end{array}$ \\
\hline \multirow{4}{*}{$\begin{array}{l}\text { (q15_9) trust-else } \\
\text { (q15_8) trust-org. } \\
\text { (q15_6) trust-science } \\
\text { (q15_3) trust-school }\end{array}$} & 0,81 & & \multirow{9}{*}{$-0,25$} & \multirow{9}{*}{$-0,03$} & \multirow{9}{*}{0,26} \\
\hline & 0,75 & & & & \\
\hline & 0,64 & & & & \\
\hline & 0,53 & & & & \\
\hline \multirow{5}{*}{$\begin{array}{r}\text { (q14_9) info-else } \\
\text { (q14_5) info-internet } \\
\text { (q14_6) info-science } \\
\text { (q14_3) info-school } \\
\text { (q14_4) info-media }\end{array}$} & \multirow[t]{5}{*}{0,50} & & & & \\
\hline & & 0,69 & & & \\
\hline & & 0,64 & & & \\
\hline & & 0,64 & & & \\
\hline & & 0,57 & & & \\
\hline (q15_4) trust-media & & & 0,79 & & \\
\hline (q15_5) trust-internet & & & 0,69 & & \\
\hline (q15_7) trust-politics & 0,34 & $-0,19$ & 0,50 & 0,05 & 0,49 \\
\hline (q15_1) trust-family & & & & 0,81 & \\
\hline (q15_2) trust-friends & & & & 0,73 & \\
\hline (q14_1) info-family & & & & 0,66 & \\
\hline (q14_2) info-friends & 0,12 & 0,39 & $-0,15$ & 0,52 & 0,12 \\
\hline (q14_7) info-politics & & & & & 0,79 \\
\hline (q14_8) info-org. & & & & & 0,50 \\
\hline
\end{tabular}

Extraction Method: PCA

Rotation Method: Varimax with Caiser Normalization; rotation converged in 19 iterations

Tab. 4 Components of CC information sources and the respondents' trust in them

In order to acquire a more specific view of the respondents, we expanded this agenda by two open questions asking the respondents to write the name of their most trustworthy and their least trustworthy subjects on the issue of CC. Assessing the results of these open questions, we may say that the least informed students trusted activists, politicians (in general) and their relatives, and they did not trust their teachers. The best informed students trusted the representatives of the Green Party, NGOs and public authorities.

However, what is most interesting are the responses related to the former Czech president and internationally recognised climate sceptic Václav Klaus. Of all 491 respondents who answered the open question "Who do you believe the least on the topic of climate change", 43.4\% (213) named him. Even though his name was not mentioned anywhere in the rest of questionnaire, distrust of him was shown by $35 \%$ of males and $49 \%$ of females (adj. residual $=2.9$; Chi-square $=0.005$ ). This distrust was exhibited nearly twice as often $(49 \%)$ in the university students' responses than in the grammar school students' responses ( $27 \%$ distrusted; adj. residual $=4,2 ;$ Chi-square $=0.0$ ). Among the respondents who did not trust Václav Klaus, $36 \%$ belonged to the well-informed group, compared to the $25 \%$ 
of the less-informed (adj. residual $=2.7 ;$ Chi-square $=0.004$ ). The respondents who distrusted Klaus also agreed less often with the statement that it is useful to live only for the moment ( $9.5 \%$ versus $16.1 \%$ of the rest; adj. residual $=2.1$; Chi-square $=0.047$ ).

\subsection{Confirmation of the hypotheses with reference to the segments}

We suggested two possible typologies which may lead to better results in grammar school and university education related to climate change: a typology of adolescents based on the information class they are linked to and on the information source they most depend on. The respondents who often seek information about CC recorded on average 5.4 correct factual responses, while the respondents who never seek that kind of information had a score of 4.5. The validity of the first survey hypothesis was thus confirmed: our survey shows that the respondents' trust in scientific sources and the effort to formulate their own opinion positively correlate with their awareness. These results, which are related to a sample of the Czech adolescent population and a particular topic, are in agreement with the results of previous surveys (Lee 2011; Milfont, 2010; Van Meergeren, 1995; Watson, 2012; Warnars, 2008).

The validity of the second compounded hypothesis was partially confirmed: the students with an extensive knowledge of CC are more often post-materialists (ANOVA; sig. 0.001 ) and they view CC negatively (Kruskal Wallis; Chi-square 30.09, sig. 0.00). Cosmopolitanism does not have an influence on the students' awareness and extensively informed students do not feel a greater concern for CC.

\section{Discussion and Conclusion}

In this explorative pilot study, we tried to confirm or rule out some previously formulated concepts (Van Meergeren, 1995; Lee, 2011; Milfont, 2010; Warnars, 2008) concerning the influence of specific information on pro-environmental attitudes. We tested several presuppositions of Warnars' study (2008) and came to the following conclusions. As well-informed students (according to q13) performed better in the CC knowledge test (q01q12), we may expect information to have some influence on long-term personal characteristics (such as worldview), which then influences personal lifestyle and thus even transient behaviour. Nevertheless, the hypotheses suggesting a direct behavioural influence were ruled out, and we may thus assume that CC information has only minor influence on respective climate-relevant behaviours (compare Warnars, 2008).

In addition to these main results, several typologies were proposed. Students at mainly grammar schools show an almost complete lack of awareness of the CC topic. Females are on average no better informed about the topic; however, they express a higher level of personal responsibility than males. For the students surveyed, the most trustworthy sources of information on the topic of climate change are generally scientists, NGO's and close family. Conversely, the students expressed distrust in climate-sceptic politicians.

Regarding the regression model and other results mentioned above, we may state that among Czech adolescents, particularly at grammar schools, awareness about climate change and the perceived responsibility for $\mathrm{CC}$ are extremely low. Attitude change could be achieved by prioritizing the topic in the grammar school curriculum and by providing motivation for scientists to engage in public debate on climate change. Our results show that this dissemination can be much more effective if the characteristics of every subgroup are taken into account and the communication strategy is related to the subgroup's specific 
needs: the least informed students in particular do not consider their teachers to be a source of trustworthy information. Generally, the lowest awareness among grammar school students is related to the processes of societal response to climate change. Thus the pilot survey supports the belief that segmented education, focused specifically on the needs of particular subgroups, should be provided more broadly.

Finally, we should mention several qualifications to these conclusions: firstly, we refer mainly to a particular population of students within the selected schools and university. Due to the effects of the self-selection of the respondents in the sample, the level of general CC knowledge within the entire of Czech student population might be even smaller. In order to prove this, further and more representative research is needed.

\section{Acknowledgments}

This text was prepared as part of the MUNI/A/1299/2014 project - Aktuální přístupy ke studiu environmentálních fenoménů [Current Approaches to the Study of Environmental Phenomena]. The complete data of the pilot study and more details of the analysis are available at http://klima.czweb.org/

\section{References}

- Ajzen, I. (1991). Theory of Planned Behaviour. Amherst: University of Massachusetts.

- Ajzen, I., Cote, G., \& N, (2008). New York: Psychology Press.

- Bamberg, S., \& Möser, G. (2007). Twenty years after Hines, Hungerford, and Tomera: A new meta-analysis of psycho-social determinants of pro-environmental behaviour. Journal of Environmental Psychology. 27, 27(1), 14-25. Retrieved from http://linkinghub.elsevier.com/retrieve/pii/S0272494406000909 http://dx.doi.org/10.1016/j.jenvp.2006.12.002

- Bas, G. (2010). The effects of multiple intelligences instructional strategy on the environmental awareness knowledge and environmental attitude levels of elementary students. International Electronic Journal of Environmental Education. (1) $1,1(1), 53-80$.

- Case, D. O. (2012). Looking for information: A survey of research on information seeking, needs and behavior. Amsterdam : Academic Press, c2002: Emerald Group Publishing. 
- Coi, (2006). Attitudes to Climate Change - Youth Sample. (Assessed on 14 September 2014). Retrieved from http://www.defra.gov.uk/environment/climatechange/uk/individual/attitudes/pdf/c cresearch-toplines-youth-0606.pdf

- Cordano, M., Frieze, I. H., \& Ellis, K. M. (2004). Entangled Affiliations and Attitudes: An Analysis of the Influences on Environmental Policy Stakeholders' Behavioral Intentions. Journal of Business Ethics, 49(1), 27-40. Retrieved from http://link.springer.com/10.1023/B:BUSI.0000013850.14353.b6 http://dx.doi.org/10.1023/B:BUSI.0000013850.14353.b6

- Dosedlová, J., Klimusová, H., Burešová, I., Jelínek, M., Slezáčková, A., \& Vašina, L. (2015). Optimism and Health-related Behaviour in Czech University Students and Adults. Procedia - Social and Behavioral Sciences, 171, 1051-1059. Retrieved from http://linkinghub.elsevier.com/retrieve/pii/S1877042815003080 http://dx.doi.org/10.1016/j.sbspro.2015.01.278

- Ďurd'ovič, M. (2013). Postoje k ochraně životního prostředí a jejímu financování. In Naše společnost - projekt kontinuálního výzkumu veřejného mínění CVVM SOÚ AV $\check{C} R$, v.v.i. Praha: Centrum pro výzkum veřejného mínění, Sociologický ústav AV ČR, v.v.i.

- European Commission (2004). Special Eurobarometer. 217/EB62.1/2004. Attitudes of European citizens towards the environment.

- European Commission (2008a). Special Eurobarometer 295/EB69.2/2008. Attitudes of European citizens towards the environment.

- European Commission (2008b). Special Eurobarometer. 300/EB69.2/2008. Europeans' attitudes towards climate change.

- European Commission (2009a). Special Eurobarometer. 313/EB71.1/2009. Europeans' attitudes towards climate change.

- European Commission (2009b). Special Eurobarometer. 322/EB72.1/2009. Europeans' attitudes towards climate change.

- European Commission (2013). Special Eurobarometer. EBS409. 2013. Europeans' attitudes towards climate change.

- European Commission (2014). Special Eurobarometer. EBS416. 2014. Attitudes of European citizens towards the environment.

- Flavin, C. (2008). Low-carbon energy: A roadmap. Worldwatch Institute: Washington.

- IPCC (2014). Summary for Policymakers. In: Climate Change 2014: Impacts, Adaptation, and Vulnerability. Part A: Global and Sectoral Aspects. Contribution of Working Group II to the Fifth Assessment Report of the Intergovernmental Panel on Climate Change [Field, C.B., V.R. Barros, D.J. Dokken, K.J. Mach, M.D. Mastrandrea, T.E. Bilir, M. Chatterjee, K.L. Ebi, Y.O. Estrada, R.C. Genova, B. Girma, E.S. Kissel, A.N. Levy, S. MacCracken, P.R. Mastrandrea, and L.L. White (eds.)]. Cambridge, United Kingdom and New York, NY, USA: Cambridge University Press. 
- Kaiser, F. G. (2006). A moral extension of the theory of planned behavior: Norms and anticipated feelings of regret in conservationism. Personality and Individual Differences, 41(1), 71-81. Retrieved from http://linkinghub.elsevier.com/retrieve/pii/S0191886906000456 http://dx.doi.org/10.1016/j.paid.2005.11.028

- Krejčí, J., Čížek, T., Vávra, M., (2012). Životní prostředí: ISSP 2010 - Česká republika. Praha: Sociologický ústav AV ČR, v.v.i.

- Lee, K. (2011). The role of media exposure, social exposure and biospheric value orientation in the environmental attitude-intention-behavior model in adolescents. Journal of Environmental Psychology, 31(4), 301-308. Retrieved from http://linkinghub.elsevier.com/retrieve/pii/S0272494411000570 http://dx.doi.org/10.1016/j.jenvp.2011.08.004

- Lorenzoni, I., Nicholson-Cole, S., \& Whitmarsh, L. (2007). Barriers perceived to engaging with climate change among the UK public and their policy implications. Global Environmental Change, 17(3-4), 445-459. Retrieved from http://linkinghub.elsevier.com/retrieve/pii/S0959378007000209 http://dx.doi.org/10.1016/j.gloenvcha.2007.01.004

- McKenzie-Mohr, D. (2013). Fostering sustainable behavior: An introduction to community-based social marketing. 2455 Teller Road, Thousand Oaks California 91320 United States : New society publishers. Retrieved from http://knowledge.sagepub.com/view/social-marketing-to-protect-theenvironment/SAGE.xml http://dx.doi.org/10.4135/9781483349466

- Mead, E., Roser-Renouf, C., Rimal, R. N., Flora, J. A., Maibach, E. W., \& Leiserowitz, A. (2012). Information Seeking About Global Climate Change Among Adolescents: The Role of Risk Perceptions, Efficacy Beliefs, and Parental Influences. Atlantic Journal of Communication, 20(1), 31-52. Retrieved from http://www.tandfonline.com/doi/abs/10.1080/15456870.2012.637027 pmid:22866024 http://dx.doi.org/10.1080/15456870.2012.637027

- Milfont, T. L., \& Duckitt, J. (2010). The environmental attitudes inventory: A valid and reliable measure to assess the structure of environmental attitudes. Journal of Environmental Psychology, 30(1), 80-94. Retrieved from http://linkinghub.elsevier.com/retrieve/pii/S0272494409000565 http://dx.doi.org/10.1016/j.jenvp.2009.09.001

- Inglehart, R. (1995). Public Support for Environmental Protection: Objective Problems and Subjective Values in 43 Societies. APSC, 28(01), 57-72. Retrieved from http://www.journals.cambridge.org/abstract S1049096500056080 http://dx.doi.org/10.1017/S1049096500056080

- Robinson, J. P., Shaver, P. R., \& Wrightsman, L. S. (Eds.)., (2013) Measures of Personality and Social Psychological Attitudes. In Measures of Social Psychological Attitudes (Vol. 1). Academic Press.

- Řeháková, B. (2004). Who are the Czech Materialists, Post-materialists, and Those Who Are 'Mixed', and How Do They Differ in Their Opinions and Attitudes on Selected - Primarily Political - Subjects. Sociologický časopis, 9(1), 35-52. 
- Schor, J. B. (2014). Climate discourse and economic downturns: The case of the United States, 2008-2013. Environmental Innovation and Societal Transitions, 13, 6-20. Retrieved from http://linkinghub.elsevier.com/retrieve/pii/S2210422414000409 http://dx.doi.org/10.1016/j.eist.2014.04.006

- Scruggs, L., \& Benegal, S. (2012). Declining public concern about climate change: Can we blame the great recession. Global Environmental Change, 22(2), 505-515. Retrieved from http://linkinghub.elsevier.com/retrieve/pii/S0959378012000143 http://dx.doi.org/10.1016/j.gloenvcha.2012.01.002

- Stevenson, K. T., Peterson, M. Nils, Bondell, H. D., Moore, S. E., \& Carrier, S. J. (2014). Overcoming skepticism with education: interacting influences of worldview and climate change knowledge on perceived climate change risk among adolescents. Climatic Change, 126(3-4), 293-304. Retrieved from http://link.springer.com/10.1007/s10584-014-1228-7 http://dx.doi.org/10.1007/s10584-014-1228-7

- Šaradin, P. (2007) Czech Republic. The Influence of the Strong Bi-polarization. In P. Šaradin \& E. Bradová (Eds.), Visegrad Votes. Parliamentary Elections 20052006. Olomouc: Univerzita Palackého.

- Van Meergeren, \& Hoofdstuk, P. (1995). Achtergronden van milieugedrag. Milieuvoorlichting. Model voor planmatige voorbereiding. Amsterdam: Boom.

- Warnars, L. (2008). Aware of the Environment? Or the Environment is aware? Nijmegen: Radboud University.

- Watson, R. T., Corbett, J., Boudreau, M. C., \& Webster, J. (2012). An information strategy for environmental sustainability. Commun. ACM, 55(7), 28-30. Retrieved from http://dl.acm.org/citation.cfm?doid $=2209249.2209261$ http://dx.doi.org/10.1145/2209249.2209261

- Wray-Lake, L., Flanagan, C. A., \& Osgood, D. W. (2010). Examining Trends in Adolescent Environmental Attitudes, Beliefs, and Behaviors Across Three Decades. Environment and Behavior, 42(1), 61-85. Retrieved from http://eab.sagepub.com/cgi/doi/10.1177/0013916509335163 pmid:20046859 http://dx.doi.org/10.1177/0013916509335163

- Zelezny, L. C. (1999). Educational Interventions That Improve Environmental Behaviors: A Meta-Analysis. The Journal of Environmental Education, 31(1), 5-14. Retrieved from http://www.tandfonline.com/doi/abs/10.1080/00958969909598627 http://dx.doi.org/10.1080/00958969909598627 
Attachment 1:

Formulation of selected batteries of questions in the questionnaire

\begin{tabular}{|c|c|c|}
\hline $\begin{array}{l}\text { [right } \\
\text { answer in } \\
\text { brackets] }\end{array}$ & $\begin{array}{l}\text { Part 1: The science of climate } \\
\text { change }\end{array}$ & $\begin{array}{l}\text { část 1: Vědecké poznání o } \\
\text { klimatické změně }\end{array}$ \\
\hline$(\mathrm{q} 01)[\mathrm{c}]$ & $\begin{array}{l}\text { Climate is defined as: } \\
\text { a) immediate sunlight, wind } \\
\text { speed and humidity } \\
\text { b) long-term average } \mathrm{CO}_{2} \\
\text { concentration in the } \\
\text { atmosphere } \\
\text { c) long-term course of the } \\
\text { weather at a given location } \\
\text { d) long-term average water } \\
\text { vapour concentration in the } \\
\text { atmosphere } \\
\text { e) periodic cycle of atmospheric } \\
\text { oscillations }\end{array}$ & $\begin{array}{l}\text { Klima je definováno jako: } \\
\text { a) okamžité oslunění, rychlost větru } \\
\text { a vlhkost } \\
\text { b) dlouhodobý průměr obsahu } \mathrm{CO}_{2} \\
\text { v atmosféře } \\
\text { c) dlouhodobý průběh počasí na } \\
\text { daném místě } \\
\text { d) dlouhodobý průměr obsahu vodní } \\
\text { páry v atmosféree } \\
\text { e) cyklus periodických } \\
\text { atmosférických oscilací }\end{array}$ \\
\hline$(q 02)[b]$ & $\begin{array}{l}\text { The term climate change is now } \\
\text { used more often than global } \\
\text { warming because: } \\
\text { a) there is no reliable evidence } \\
\text { for the increase in average } \\
\text { temperatures } \\
\text { b) temperature in certain places } \\
\text { is dropping } \\
\text { c) it is not the globe that is getting } \\
\text { warmer, but the atmosphere } \\
\text { d) most of the warming is in the } \\
\text { Northern Hemisphere } \\
\text { e) the concept of global warming } \\
\text { is difficult to translate and it } \\
\text { used to provoke hysteria }\end{array}$ & $\begin{array}{l}\text { Termín změna klimatu se nyní } \\
\text { používá častěji než globální } \\
\text { oteplování, protože: } \\
\text { a) zvyšování průměrných teplot } \\
\text { není spolehlivě prokázáno } \\
\text { b) teplota na některých místech } \\
\text { klesá } \\
\text { c) se neotepluje zemský glóbus, ale } \\
\text { pouze atmosféra } \\
\text { d) se převážně otepluje na severní } \\
\text { polokouli } \\
\text { e) pojem globální oteplování je } \\
\text { obtížně přeložitelný a vyvolával } \\
\text { hysterii }\end{array}$ \\
\hline$(\mathrm{q03})[\mathrm{a}]$ & $\begin{array}{l}\text { The essence of the greenhouse } \\
\text { effect is the fact that: } \\
\text { a) Heat radiation is prevented } \\
\text { from freely leaving the } \\
\text { atmosphere. } \\
\text { b) Sunlight is prevented from } \\
\text { freely leaving the atmosphere. } \\
\text { c) Greenhouse gases are } \\
\text { attracting more radiation from } \\
\text { space. } \\
\text { d) Solar activity is increasing, and } \\
\text { therefore Earth is receiving } \\
\text { more radiation. } \\
\text { e) Solar activity is decreasing, and } \\
\text { therefore Earth is receiving less } \\
\text { radiation. }\end{array}$ & $\begin{array}{l}\text { Podstatou skleníkového efektu je } \\
\text { fakt, že: } \\
\text { a) Tepelnému záření je bráněno ve } \\
\text { volném odchodu z atmosféry. } \\
\text { b) Slunečnímu záření je bránéno ve } \\
\text { volném odchodu z atmosféry. } \\
\text { c) Skleníkové plyny k sobě přitahují } \\
\text { více záření z vesmíru. } \\
\text { d) Sluneční aktivita roste, a proto } \\
\text { Země přijímá více záření. } \\
\text { e) Sluneční aktivita klesá, a proto } \\
\text { Země přijímá méně záření. }\end{array}$ \\
\hline
\end{tabular}




\begin{tabular}{|c|c|c|}
\hline$(\mathrm{q04})[\mathrm{d}]$ & $\begin{array}{l}\text { The gases that have a significant } \\
\text { impact on the temperature of } \\
\text { Earth's atmosphere do not } \\
\text { include: } \\
\text { a) methane } \\
\text { b) CO2 } \\
\text { c) steam } \\
\text { d) oxygen } \\
\text { e) nitrous oxide }\end{array}$ & $\begin{array}{l}\text { Mezi plyny, které mají výrazný vliv } \\
\text { na teplotu zemské atmosféry } \\
\text { nepatř́: } \\
\text { a) metan } \\
\text { b) CO2 } \\
\text { c) vodní pára } \\
\text { d) kyslík } \\
\text { e) oxid dusný }\end{array}$ \\
\hline$(\mathrm{q05})[\mathrm{c}]$ & $\begin{array}{l}\text { Over the last hundred years the } \\
\text { global average temperature: } \\
\text { a) has decreased by } 0.7^{\circ} \mathrm{C} \\
\text { b) has not changed } \\
\text { c) has increased by } 0.7^{\circ} \mathrm{C} \\
\text { d) has increased by } 1.7^{\circ} \mathrm{C} \\
\text { e) has increased by } 7^{\circ} \mathrm{C}\end{array}$ & $\begin{array}{l}\text { Za posledních sto let globální prům. } \\
\text { teplota: } \\
\text { a) klesla o } 0,7^{\circ} \mathrm{C} \\
\text { b) se nepromemnila } \\
\text { c) stoupla o } 0,7^{\circ} \mathrm{C} \\
\text { d) stoupla o } 1,7^{\circ} \mathrm{C} \\
\text { e) stoupla o } 7^{\circ} \mathrm{C}\end{array}$ \\
\hline$(q 06)[d]$ & $\begin{array}{l}\text { How strong is the scientific } \\
\text { certainty of the claim that it is } \\
\text { humans who are causing climate } \\
\text { change?: } \\
\text { a) } 0 \% \text { (This statement is a lie.) } \\
\text { b) } 10 \% \text { (It is highly unlikely.) } \\
\text { c) } 50 \% \text { (It is possible). } \\
\text { d) } 90 \% \text { (It is very likely.) } \\
\text { e) } 100 \% \text { (It is completely certain.) }\end{array}$ & $\begin{array}{l}\text { Jak velká je vědecká jistota tvrzení, } \\
\text { že lidé zpưsobují změnu klimatu: } \\
\text { a) } 0 \% \text { (Toto tvrzení je lež.) } \\
\text { b) } 10 \% \text { (Je to velmi } \\
\text { nepravděpodobné.) } \\
\text { c) } 50 \% \text { (Je to možné.) } \\
\text { d) } 90 \% \text { (Je to velmi } \\
\text { pravděpodobné.) } \\
\text { e) } 100 \% \text { (Je to jisté.) }\end{array}$ \\
\hline
\end{tabular}

\begin{tabular}{|c|c|c|}
\hline & $\begin{array}{l}\text { Part 2: Societal response to } \\
\text { climate change }\end{array}$ & $\begin{array}{l}\text { část 2: Společenská reakce na } \\
\text { klimatickou změnu }\end{array}$ \\
\hline$(\mathrm{q07})[\mathrm{c}]$ & $\begin{array}{l}\text { Carbon footprint is: } \\
\text { a) spatial specification of areas } \\
\text { with supplies of fossil fuels } \\
\text { b) mitigation program based on } \\
\text { the promotion of hiking } \\
\text { c) definition of the amount of } \\
\text { emissions } \\
\text { d) program investigating the } \\
\text { carbon dioxide content in } \\
\text { glaciers } \\
\text { e) a method of the World } \\
\text { Meteorological Organization } \\
\text { for research of atmospheric } \\
\text { carbon compounds }\end{array}$ & $\begin{array}{l}\text { Uhlíková stopa je: } \\
\text { a) prostorové vymezení oblastí se } \\
\text { zásobami fosilních paliv } \\
\text { b) program na snižovaní emisí } \\
\text { podporou pěší turistiky } \\
\text { c) vymezení emisní náročnosti } \\
\text { d) program zkoumající obsah oxidu } \\
\text { uhličitého v ledovcích } \\
\text { e) metoda Světové meteorologické } \\
\text { organizace pro výzkum } \\
\text { atmosférických sloučenin uhlíku }\end{array}$ \\
\hline$(\mathrm{q08})[\mathrm{a}]$ & $\begin{array}{l}\text { Environmental taxes always: } \\
\text { a) are related to the } \\
\text { internalisation of external costs } \\
\text { into product prices } \\
\text { b) are defined by the scientific } \\
\text { part of the Intergovernmental } \\
\text { Panel on Climate Change } \\
\text { c) serve as a contribution to } \\
\text { species conservation }\end{array}$ & $\begin{array}{l}\text { Ekologické daně vždy: } \\
\text { a) souvisejí se zahrnutím nepřímých } \\
\text { nákladů do ceny produktů } \\
\text { b) definuje vědecká část } \\
\text { Mezivládního klimatického panelu } \\
\text { c) slouží jako příspěvek na } \\
\text { druhovou ochranu prírody } \\
\text { d) mají dopad pouze na právnické } \\
\text { osoby }\end{array}$ \\
\hline
\end{tabular}




\begin{tabular}{|c|c|c|}
\hline & $\begin{array}{l}\text { d) have an impact only on legal } \\
\text { subjects } \\
\text { e) are an auxiliary, not a legally } \\
\text { binding, instrument of the UN }\end{array}$ & $\begin{array}{l}\text { e) jsou pomocným nástrojem OSN } \\
\text { bez právní závaznosti }\end{array}$ \\
\hline$(\mathrm{q09})[\mathrm{c}]$ & $\begin{array}{l}\text { Intergovernmental Panel on } \\
\text { Climate Change: } \\
\text { a) develops international } \\
\text { political agreements leading } \\
\text { to a decrease in emissions. } \\
\text { b) does climate research. } \\
\text { c) collects and publishes } \\
\text { comprehensive scientific } \\
\text { findings. } \\
\text { develops methods to cope } \\
\text { with climate change. } \\
\text { e) creates legal norms for a } \\
\text { carbon-free economy of the } \\
\text { 21st century. }\end{array}$ & $\begin{array}{l}\text { Mezivládní klimatický panel se } \\
\text { zabývá: } \\
\text { a) Uzavíráním mezinárodních } \\
\text { politických dohod směřujících k } \\
\text { poklesu emisí. } \\
\text { b) Výzkumem klimatu. } \\
\text { c) Shromažd'ováním a souhrnným } \\
\text { publikováním vědeckých } \\
\text { poznatků. } \\
\text { d) Vývojem metod, jak změně } \\
\text { klimatu čelit. } \\
\text { e) Tvorbou právních norem pro } \\
\text { soužití v bezuhlíkové ekonomice } \\
21 . \text { století. }\end{array}$ \\
\hline$(\mathrm{q} 10)[\mathrm{c}]$ & $\begin{array}{l}\text { The Stern report says: } \\
\text { a) the number of polar bears has } \\
\text { doubled } \\
\text { b) the number of polar bears has } \\
\text { fallen by half } \\
\text { c) it is significantly more } \\
\text { profitable to invest in measures } \\
\text { to combat climate change than } \\
\text { to bear its consequences } \\
\text { d) it is preferable to bear the } \\
\text { consequences of climate } \\
\text { change rather than to invest in } \\
\text { measures against it } \\
\text { e) current climatological findings } \\
\text { are not a sufficient basis for } \\
\text { political decisions }\end{array}$ & $\begin{array}{l}\text { Sternova zpráva říká, že: } \\
\text { a) počet ledních medvědů vzrostl na } \\
\text { dvojnásobek } \\
\text { b) počet ledních medvědů klesı na } \\
\text { polovinu } \\
\text { c) je výhodnější výrazněji } \\
\text { investovat do opatření proti } \\
\text { klimatické změně, než nést její } \\
\text { následky } \\
\text { d) je výhodnější nést následky } \\
\text { klimatické změny, než nyní } \\
\text { výrazněji investovat do opatření } \\
\text { proti ní } \\
\text { e) současná klimatologická zjištění } \\
\text { nejsou dostatečným podkladem } \\
\text { pro politická rozhodnutí }\end{array}$ \\
\hline$(\mathrm{q} 11)[\mathrm{c}]$ & $\begin{array}{l}\text { Climate prediction scenarios claim } \\
\text { that: } \\
\text { a) the temperature rise in this } \\
\text { century will very likely be } \\
\text { smaller than in the } 20^{\text {th }} \text { century } \\
\text { b) the temperature rise in this } \\
\text { century will very likely be the } \\
\text { same as in the } 20^{\text {th }} \text { century } \\
\text { c) the temperature rise in this } \\
\text { century will very likely be larger } \\
\text { than in the } 20^{\text {th }} \text { century global } \\
\text { d) developments in cannot be } \\
\text { temperatures can } \\
\text { predicted because they depend } \\
\text { on too many factors }\end{array}$ & $\begin{array}{l}\text { Ve scénáŕích vývoje klimatu se tvrdí, } \\
\text { že: } \\
\text { a) nárůst teploty v tomto století } \\
\text { bude velmi pravděpodobně } \\
\text { menší než ve } 20 \text {. století } \\
\text { b) nárůst teploty v tomto století } \\
\text { bude velmi pravděpodobně } \\
\text { stejný jako ve } 20 \text {. století } \\
\text { c) nárưst teploty v tomto století } \\
\text { bude velmi pravděpodobně větší } \\
\text { než ve } 20 \text {. století } \\
\text { d) vývoj globální teploty nelze } \\
\text { předpovědět, protože závisí na } \\
\text { přiliš mnoha faktorech } \\
\text { e) mořská hladina vystoupí o šest } \\
\text { až dvacet metrů a zaplaví } \\
\text { kontinentální pobřeží }\end{array}$ \\
\hline
\end{tabular}




\begin{tabular}{|c|c|c|}
\hline & $\begin{array}{l}\text { e) the sea level is going to rise by } \\
\text { six to twenty meters and flood } \\
\text { the continental coast }\end{array}$ & \\
\hline$(q 12)[c]$ & $\begin{array}{l}\text { Current climate policy does not } \\
\text { include: } \\
\text { a) the integration of climate } \\
\text { concerns into development } \\
\text { policies } \\
\text { b) The Kyoto Protocol } \\
\text { c) a commitment to reduce global } \\
\text { emissions by } 2020 \text { at least by } 5 \% \\
\text { d) "Energy Package of the } \\
\text { European Union" } \\
\text { e) emission allowances }\end{array}$ & $\begin{array}{l}\text { Současné politiky ochrany klimatu } \\
\text { nezahrnují: } \\
\text { a) začlenění hlediska klimatu do } \\
\text { rozvojových politik } \\
\text { b) Kjótský protokol } \\
\text { c) závazek snížit do roku } 2020 \\
\text { globální emise aspoň o } 5 \% \\
\text { d) "Evropský energetický balíček" } \\
\text { e) emisní povolenky }\end{array}$ \\
\hline
\end{tabular}

\begin{tabular}{|c|c|c|}
\hline & $\begin{array}{l}\text { Information on Climate } \\
\text { Change }\end{array}$ & Informace o změně klimatu \\
\hline (q13) & $\begin{array}{l}\text { How often do you look for } \\
\text { information about climate } \\
\text { change? } \\
\text { a) very often } \\
\text { b) often } \\
\text { c) sometimes } \\
\text { d) rarely } \\
\text { e) never }\end{array}$ & $\begin{array}{l}\text { Jak obvykle si sami vyhledáváte } \\
\text { informace o klimatické změně? } \\
\text { a) velmi často } \\
\text { b) často } \\
\text { c) občas } \\
\text { d) málo } \\
\text { e) nikdy }\end{array}$ \\
\hline
\end{tabular}

\begin{tabular}{|l|l|l|}
\hline & Self-reported responsibility & Hodnocení vlastní odpovědnosti \\
\hline (q20) & $\begin{array}{l}\text { Do you feel personal } \\
\text { responsibility for climate change? } \\
\text { a) definitely yes }\end{array}$ & $\begin{array}{l}\text { Cítíte vlastní odpovědnost za změnu } \\
\text { klimatu? } \\
\text { a) rozhodně ano } \\
\end{array}$ \\
& b) somewhat & b) spíše ano \\
& c) not particularly & c) spíše ne \\
& d) definitely no & d) rozhodně ne \\
\hline
\end{tabular}

\begin{tabular}{|l|l|l|}
\hline & Evaluation of Climate Change & Hodnocení změny klimatu \\
\hline (q22) & $\begin{array}{l}\text { I evaluate climate change as: } \\
\text { e) definitely positive }\end{array}$ & $\begin{array}{l}\text { Změnu klimatu hodnotím: } \\
\text { a) rozhodně pozitivně }\end{array}$ \\
& f) somewhat positive & b) spíše pozitivně \\
& g) somewhat negative & c) ríše negativně \\
& h) definitely negative & e) nevím \\
& i) I do not know & \\
\hline
\end{tabular}

